\title{
Keanekaragaman Musuh Alami Tanaman Padi pada Lahan Lebak di Tiga Desa Kecamatan Sungai Pandan Kabupaten HSU
}

\section{(Diversity of Natural Enemies of Rice Plants on Lebak Wetlands In Three Village Sungai Pandan District HSU Regency)}

\author{
Farida Adriani ${ }^{1)}$ \& Nur Hafizah ${ }^{2)}$ \\ Program Studi Agroteknologi, Sekolah Tinggi Ilmu Pertanian Amuntai \\ 1)adrianifr9@gmail.com \\ 2)fifi_bjm@yahoo.co.id
}

\begin{abstract}
ABSTRAK
Pemanfaatan keanekaragaman serangga berguna dalam mengatasi hama di lapangan, dengan menggunakan parasitoid dan predator untuk mengendalikan hama, dapat mencegah penggunaan bahan kimia beracun di lapangan, sambil memberikan tempat yang aman bagi spesies lain untuk hidup dan memainkan perannya dalam memelihara kesehatan ekosistem. Keragaman serangga di Kalimantan Selatan, terutama sawah di daerah rawa sebagian besar tidak diketahui, dan karena itu perlu diperiksa. Tujuan dari penelitian ini adalah untuk mengidentifikasi dan menilai keanekaragaman musuh alami pada tanaman padi di daerah rawa, terutama di tiga desa di Kabupaten Sungai Pandan, Hulu Sungai Utara. Penelitian ini dilakukan mulai Februari - Juni 2015. Metode yang digunakan dalam penelitian ini adalah metode survei dengan pengamatan langsung dengan luas lahan sawah yang telah ditentukan, dan pengambilan sampel musuh alami arthropoda dengan menggunakan jaring ayun, perangkap air dan perangkap cahaya. Hasil dari penelitian ini adalah: (1) Jumlah musuh alami arthropoda yang ditemukan di daerah rawa dangkal adalah 20 spesies dari tujuh ordo, rawa pertengahan dan dalam masing-masing terdapat 16 spesies dari tujuh ordo; (2) Populasi arthropoda predator yang paling tinggi di daerah rawa dangkal adalah Micraspis sp., rawa tengahan adalah fuscipes Paederus, dan rawa dalam adalah Micraspis sp. ; dan (3) indeks keanekaragaman musuh alami arthropoda di daratan ketiga adalah rendah.
\end{abstract}

Kata kunci: Keanekaragaman hayati, musuh alami, padi, daerah rawa.

\section{ABSTRACT}

Utilization of insect diversity is useful in overcoming pest in the field, by using parasitoids and predators to control pests, can prevent the use of toxic chemicals in the field, while providing a safe haven for other species to live and play its role in maintaining the health of the ecosystem. Insect diversity in South Kalimantan, especially paddy fields in swampy areas largely unknown, and therefore need to be examined. The aim of this study is to identify and assess the diversity of natural enemies in paddy crop in swampy areas, especially in the three villages in the district of Sungai Pandan, Hulu Sungai Utara. This study was conducted from February - June 2015. The method used in this research is survey method with direct observation with an area of rice fields has been determined, and sampling arthropod natural enemies by using a swinging nets, water traps and light traps. Results from this study are: (1) The number of arthropod natural enemies found in shallow swamps is 20 species from seven orders, mid swamps and in each of the 16 species of seven orders; (2) The highest predator arthropod population in the shallow swamp area is Micraspis sp., The middle swamp is Paederus fuscipes, and the deep swamp is Micraspis sp. ; and (3) the diversity index of natural enemies of arthropods on the third mainland is low.

Keywords: Biodiversity, natural enemies, rice, wetland areas.

PENDAHULUAN

Provinsi Kalimantan Selatan dengan luas wilayah 3.753.052 ha, diantaranya terdapat lahan lebak seluas 208.893 ha dan Kabupaten Hulu Sungai Utara merupakan lebak terluas di Kalimantan Selatan (Dinas Pertanian dan
Hortikultura Provinsi Kalimantan Selatan, 2012). Kegiatan usahatani masyarakat di Kecamatan Sungai Pandan adalah usaha tani tanaman padi dan sayuran. Usahatani padi ditanam hanya sekali setahun, untuk itulah kualitas dan kuantitas padi harus terus ditingkatkan. Salah satu faktor yang 
mempengaruhi kualitas dan kuantitas padi adalah hama dan penyakit,karena apabila pertanaman padi terserang hama dan penyakit tersebut maka dapat mengakibatkan produksi padi akan menurun.

Cara pengendalian hama dan penyakit padi biasanya terdiri dari beberapa macam, salah satu pengendalian yang sering dilakukan petani adalah dengan menggunakan pestisida. Namun pestisida ternyata dapat menimbulkan dampak negatif yang tidak diinginkan antara lain terjadinya resistensi OPT, timbulnya OPT sekunder karena terbunuhnya musuh alami, resurjensi dan kasus-kasus keracunan serta terancamnya hasil pertanian oleh residu pestisida (Simanungkalit, 2004).

Menurut Sosromarsono dan Untung (2007), bahwa pestisida kimia khususnya insektisida mempunyai dampak yang sangat merugikan bagi keanekaragaman hayati serangga termasuk artropoda dan parasitoid, terutama insektisida yang berspektrum luas. Resurjensi serangga hama setelah aplikasi insektisida disebabkan karena tertekannya musuh alami serangga hama itu.

Pada umumnya petani mengatasi serangga hama dengan tujuan pengendalian hama saja, tanpa memperhatikan keanekaragaman hayati pada ekosistem pertaniannya. Padahal teknik budidaya padi tanpa menggunakan pestisida dapat meningkatkan keanekaragaman hayati pada ekosistem tersebut sehingga musuh alami yang hadir dapat berperan secara maksimal dalam mengatur populasi hama.

Oleh karena itu, meskipun hama hadir dipertanaman, tingkat populasinya rendah, dengan kata lain populasi hama berada pada keadaan stabil. Pemanfaatan keanekaragaman serangga berguna dalam mengatasi hama di lapangan, dengan memanfaatkan parasitoid dan predator untuk mengendalikan hama, penggunaan racun kimia di lapangan dapat dicegah, sekaligus memberikan tempat yang aman bagi spesies lain untuk hidup dan memainkan peranannya dalam menjaga kesehatan ekosistem.

Keanekaragaman serangga di Kalimantan Selatan khususnya persawahan di lahan lebak belum banyak diketahui, oleh sebab itu perlu diteliti. Tujuan dari penelitian ini adalah untuk mengidentifikasi dan mengkaji keanekaragaman musuh alami pada pertanaman padi di lahan lebak khususnya di tiga desa yang ada di Kecamatan Sungai Pandan Kabupaten Hulu Sungai Utara.

Hasil yang didapat dari penelitian ini diharapkan dapat menjadi salah satu bahan informasi bagi para akademisi, petani maupun pemerintah daerah dalam mengatasi hama tanaman padi di persawahan, dengan memanfaatkan parasitoid dan predator untuk mengendalikan hama sehingga dapat menjaga keseimbangan ekosistem dalam pengembangan pertanian berkelanjutan. Selain itu juga dapat memperkaya khasanah bahan ajar di perguruan tinggi peneliti yang berkonsentrasi pada lahan rawa, khususnya pada mata kuliah yang di ampu oleh peneliti.

Tingkat keanekaragaman dan kelimpahan organisme dalam suatu komunitas berbedabeda dan untuk mempelajari keanekaragaman suatu spesies dalam ekosistem dapat diukur dengan mengetahui keanekaragaman jenisnya.

Kelimpahan ("abudance") adalah jumlah individu dalam suatu areal (tempat) tertentu. Suatu komunitas itu disusun oleh banyak spesies (jenis) dengan kelimpahan spesies yang sama/hamper sama atau mempunyai dominasi yang rendah. Sebaliknya jika komunitas itu disusun oleh sedikit spesies dan dengan dominasi yang tinggi maka keanekaragaman jenisnya rendah. Keanekaragaman jenis yang tinggi menunjukkan bahwa komunitas tersebut memiliki kompleksitas yang tinggi dengan interaksi spesies yang tinggi pula (Soegianto, 2004).

Secara umum populasi organisme di alam berada dalam keadaan seimbang pada jenjang populasi tertentu. Hal itu disebabkan oleh faktor-faktor lingkungan dan juga faktor dalam populasi itu sendiri yang mengendalikan populasi tersebut. Salah satu kelompok factor lingkungan tersebut adalah predator dan parasit. Serangga predator dan parasitoid adalah faktor penting dalam pengendalian alamiah populasi serangga pada umumnya (Sosromarsono dan Untung, 2007).

Secara alamiah akan terjadi interaksi diantara semua komponen dalam ekosistem sehingga membentuk susunan jaring-jaring rantai makanan, yang masing-masing 
kelompoknya saling memerlukan untuk kelangsungan hidupnya. Musuh alami seperti parasitoid dan predator sebagai pengatur populasi di alam meruapakan faktor biotik yang mempunyai peranan paling besar dalam menjaga keseimbangan ekosistem. Musuh alami sebagai faktor tergantung kepadatan populasi atau density dependent factors peranannya sangat tergantung pada populasi mangsa.

Karena kebayakan predator bersifat polifag, keberadannya memerlukan dukungan dari tersedianya sumber pakan alternatif yang dapat dipenuhi oleh populasi serangga netral. Dalam keaadaan seperti ini peran serangga netral sangat diperlukan untuk menjaga kelestarian musuh alami supaya akhirnya tercapai keseimbangan antara hama dan musuh alami (Mahrub, 2004).

Predator adalah binatang atau serangga yang memakan binatang atau serangga lain. Istilah predasi adalah suatu bentuk simbiosis (hubungan) dari dua individu, dimana salah satu individu menyerang atau memakan individu lain (dapat satu atau beberapa spesies) yang digunakan untuk kepentingan hidupnya dan biasanya dilakukan berulangulang. Individu yang diserang atau dimakan dinamakan mangsa. Predator memilki ciri antara lain: ukuran tubuh lebih besar daripada mangsa, ada yang bersifat monofag, oligofag, dan polifag. Predator membunuh dan memakan atau menghisap mangsanya dengan cepat dan biasanya predatoe memerlukan dan memakan banyak mangsa selama hidupnya (Jumar, 2004).

Parasitisme adalah suatu peristiwa yang disebabkan oleh adanya organisme yang bersifat sebagai parasit. Parasitoid adalah serangga yang hidup menumpang, berlindung atau mkan dari serangga lain yang dinamakan inang dan dapat mematika inangnya secara perlahan-lahan. Satu individu parasitoid hanya menerlukan satu individu inang untuk berkembang secara normal sampai dewasa. Parasitoid biasanya hanya memerlukan inangnya pada stadia dewasa, sedangkan pada saat dewasa hidup bebas. Parasitoid dapat menyerang dan berkembang dalan satu atau beberapa fase hidup inang. Misalnya : parsitoid telur, parasitoid telur-larva, parasitoid larva-pupa, parasitoid pupa, dan lain-lain (Jumar, 2004).

Lahan rawa lebak mempunyai ciri yang sangat khas, pada musim hujan terjadi genangan air yang melimpah dalam variasi kurun waktu yang cukup lama. Genangan air dapat kurang dari satu bulan sampai enam bulan atau lebih, dengan ketinggian genangan $50-100 \mathrm{~cm}$. Air yang menggenang tersebut bukan merupakan limpasan air pasang, tetapi berasal dari limpasan air permukaan yang terakumulasi di wilayah tersebut karena topografinya yang rendah dan drainasenya jelek. Kondisi genangan air sangat dipengaruhi oleh curah hujan, baik di daerah tersebut maupun wilayah sekitarnya serta daerah hulu (Ar-Riza et al., 2008). Tujuan penelitian ini adalah untuk mengidentifikasi dan menilai keanekaragaman musuh alami pada tanaman padi di daerah rawa, terutama di tiga desa di Kabupaten Sungai Pandan, Hulu Sungai Utara.

\section{METODE PENELITIAN}

Penelitian ini dilaksanakan di areal sawah lahan lebak di Desa Banyu Tajun Pangkalan, Rantau Karau Raya, dan Teluk Sinar, Kecamatan Sungai Pandan Kabupaten Hulu Sungai Utara. Penelitian ini dilaksanakan mulai bulan Pebruari - Juni 2015.

\section{Metode Penelitian}

Metode yang digunakan dalam penelitian ini adalah metode survey dengan pengamatan langsung di lokasi persawahan dengan luasan yang telah ditentukan, dan pengambilan sampel artropoda musuh alami dengan menggunakan jaring ayun, perangkap air dan lampu perangkap.

\section{Pelaksanaan Penelitian}

Penentuan Lokasi. Untuk mengetahui keanekaragaman artropoda musuh alami pada pertanaman padi di lahan lebak ditentukan petak luasan $1.445 \mathrm{~m}^{2}$ (lima borongan). Pada luasan tersebut dipasang dua buah lampu perangkap untuk menangkap artropoda yang bersifat nokturnal. Kemudian ditentukan juga lima buah sub petak sampel dengan ukuran 1 $\mathrm{x} 1 \mathrm{~m}^{2}$ untuk pengamatan langsung dan pengambilan contoh artropoda dengan 
menggunakan perangkap air. Disamping penangkapan dengan lampu perangkap dan perangkap air, juga digunakan jaring serangga. Penangkapan serangga dengan jaring serangga dengan cara mengayunkan 10 kali ayunan ganda pada lima sub petak yang digunakan sebagai petak penangkapan perangkap air.

Pengamatan. Dilakukan selama 3 bulan pada fase vegetatif sampai padi menjelang panen dengan interval waktu sampai satu minggu sekali. Tanaman padi yang diamati adalah pertanaman padi Varietas Mekongga. Pengamatan dilakukan terhadap artropoda musuh alami yang tertangkap dengan jaring serangga, perangkap air dan lampu perangkap. Artropoda yang tertangkap selanjutnya di bawa ke laboratorium untuk dilakukan identifikasi dengan menggunakan metode Siswanto dan Trisawa (2000):

1. Menggunakan kunci determinasi

2. Membandingkan dengan gambar-gambar yang ada

3. Membandingkan dengan koleksi yang telah diidentifikasi

4. Menanyakan pada ahlinya atau pada orang yang sudah berpengalaman

5. Kombinasi dati dua atau lebih cara identifikasi

Kunci identifikasi digunakan sampai tingkat ordo, family, dan beberapa serangga sampai tingkat spesies, sedangkan buku acuan yang digunakan untuk mengidentifikasi bersumber dari beberapa bahan referensi rujukan.

\section{Pengolahan Data}

Hasil pengamatan yang telag diperoleh berbagai spesies artropoda predator dan parasitoid dihitung berdasarkan atas jumlah family dan spesiesnya.

Indeks dominasi (C) dihitung menggunakan rumus menurut Ludwig \& Reynold (1988):

Keterangan:

$$
c=\sum(n i / N
$$

ni $=$ Jumlah total individu dari suatu spesies

$\mathrm{N}=$ Jumlah total individu dari seluruh spesies Indeks keragaman (H') dihitung berdasarkan rumus menurut Sahnnon-Weaver (Southwood, 1978 dalam Ludwig dan Reynold, 1998), sebagai berikut :
Keterangan:

$$
H^{\prime}=-\sum p i \operatorname{In} p i
$$

pi $=$ Proporsi spesies ke-I di dalam sampel total

Tingkat kesamaan (E) dihitung menggunakan rumus menurut Pielou (1984) dan Ludwig \& Reynold (1988):

$$
E=H^{\prime} / \operatorname{In} S
$$

Keterangan:

$\mathrm{H}^{\prime}=$ Indeks keragaman

$\mathrm{S}=$ Jumlah seluruhnya

Indeks kekayaan jenis (R) dihitung menggunakan rumus menurut Margalef (Ludwig \& Reynold, 1988):

$$
R=\frac{S-1}{I n N}
$$

Keterangan:

$\mathrm{S}=$ Jenis seluruhnya

$\mathrm{N}=$ Jumlah jenis seluruhnya.

\section{HASIL DAN PEMBAHASAN Hasil}

\section{Lahan Lebak Dangkal}

Berdasarkan hasil pengamatan dan identifikasi terhadap tangkapan artropoda musuh alami yang dilakukan peda lahan lebak dangkal, artropoda yang didapat terdiri dari 20 species yang terbagi dalam tujuh ordo yaitu ordo Areneae (enam spesies), Coleoptera (empat spesies), Diptera (dua spesies), Hemiptera (dua spesies), Hymenoptera (empat spesies), Odonata (satu spesies), Orthoptera (satu spesies) (Tabel 2). Secara grafik histogram, populasi dari artopoda berdasarkan ordo yang didapat pada lahan lebak dangkal disajikan pada Gambar 1. 
Farida Adriani \& Nur Hafizah, Keanekaragaman musuh alami...

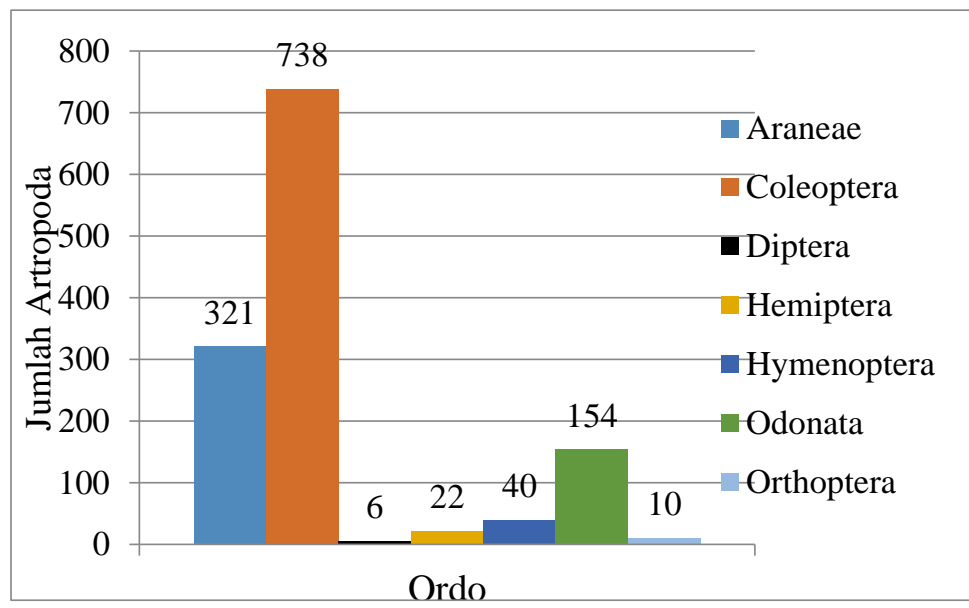

Gambar 1. Histogram populasi artropoda musuh alami yang didapat pada lahan lebak dangkal.

Tabel 1. Spesies arthropoda musuh alami serta statusnya pada lahan lebak dangkal di Desa Banyu Tajun Pangkalan Kecamatan Sungai Pandan Kabupaten Hulu Sungai Utara.

\begin{tabular}{|c|c|c|c|c|}
\hline No. & Spesies (Jenis) & Famili (Keluarga) & Ordo (Bangsa) & Jumlah (ekor) \\
\hline A & Predator & & & \\
\hline 1 & Argiope catenulata & Araneidae & Araneae & 10 \\
\hline 2 & Atypena formosana & Lynyphiidae & Araneae & 42 \\
\hline 3 & Lycosa pseudoannulata & Lycosidae & Araneae & 172 \\
\hline 4 & Oxyopes javanus & Oxyopidae & Araneae & 5 \\
\hline 5 & Phidippus sp. & Salticidae & Araneae & 50 \\
\hline 6 & Tetragnatha sp. & Tetragnathidae & Araneae & 42 \\
\hline 7 & Harmonia octomaculata & Coccinellidae & Coleoptera & 5 \\
\hline 8 & Micraspis sp. & Coccinellidae & Coleoptera & 301 \\
\hline 9 & Ophionea sp. & Carabidae & Coleoptera & 161 \\
\hline 10 & Paederus fuscipes & Staphylinidae & Coleoptera & 271 \\
\hline 11 & Anatrichus pygmaeus & Chloropidae & Diptera & 4 \\
\hline 12 & Limnogonus sp. & Gerridae & Hemiptera & 3 \\
\hline 13 & Microvelia dauglasi & Vellidae & Hemiptera & 19 \\
\hline 14 & Agriocnemis femina femina & Coenagrionidae & Odonata & 154 \\
\hline 15 & Conocephalus longipennis & Tettigoniidae & Orthoptera & 10 \\
\hline \multicolumn{4}{|c|}{ Jumlah (ekor) } & 1.249 \\
\hline B & Parasitoid & & & \\
\hline 1 & Pipunculus mutillatus & Pipunculidae & Diptera & 2 \\
\hline 2 & Anagrus optabilis & Mymaridae & Hymenoptera & 14 \\
\hline 3 & Apanteles baolis & Braconidae & Hymenoptera & 5 \\
\hline 4 & Telenomus rowani & Scelionidae & Hymenoptera & 16 \\
\hline 5 & Tertastichus schoenobli & Eulophidae & Hymenoptera & 5 \\
\hline \multicolumn{4}{|c|}{ Jumlah (ekor) } & 42 \\
\hline \multicolumn{4}{|c|}{ Jumlah $(A+B)$} & 1291 \\
\hline
\end{tabular}

Berdasarkan statusnya, arthropoda musuh alami yang diperoleh di lahan lebak dangkal yang berperan sebagai predator sebanyak 15 spesies dan yang berperan sebagai parasitoid sebanya 5 spesies.
Populasi arthropoda predator tertinggi pada lahan lebak dangkal adalah Micraspis sp., diikuti oleh Paederus fuscipes, Lycosa pseudoannulata, Ophionea sp., dan Agrionemis femina femina, sedangkan antropoda predator lainnya dalam jumlah 
rendah. Populasi antropada parasitoid tertinggi adalah Telenomus rowani dan Anagrus optabilis sedangkan arthropoda parasitoid lainnya dalam jumlah rendah.

\section{Lahan Lebak Tengahan}

Arthropoda musuh alami yang didapat pada lahan lebak tengahan terdiri dari 16 spesies yang terbagi dalam 7 ordo yaitu ordo
Araneae (enam spesies), Coleoptera (tiga spesies), Diptera (satu spesies), Hemiptera (dua spesies), Hymenoptera (dua spesies), Odonata (satu spesies) dan Orthoptera (satu spesies) (Tabel 2). Hubungan antara orodo dan populasi antropoda yang didapat pada lahan lebak tengahan disajikan pada Gambar 2.

Tabel 2. Spesies antropoda musuh alami serta statusnya pada lahan lebak tengahan di Desa Teluk Sinar Kecamatan Sungai Pandan Kabupaten Hulu Sungai Utara.

\begin{tabular}{llllc}
\hline No. & \multicolumn{1}{c}{ Spesies (Jenis) } & Famili (Keluarga) & Ordo (Bangsa) & Jumlah (ekor) \\
\hline A & Predator & & & \\
1 & Argiope catenulata & Araneidae & Araneae & 17 \\
2 & Atypena formosana & Lynyphiidae & Araneae & 11 \\
3 & Lycosa pseudoannulata & Lycosidae & Araneae & 119 \\
4 & Oxyopes javanus & Oxyopidae & Araneae & 86 \\
5 & Phidippus sp. & Salticidae & Araneae & 57 \\
6 & Tetragnatha sp. & Tetragnathidae & Araneae & 75 \\
7 & Micraspis sp. & Coccinellidae & Coleoptera & 162 \\
8 & Ophionea sp. & Carabidae & Coleoptera & 223 \\
9 & Paederus fuscipes & Staphylinidae & Coleoptera & 290 \\
10 & Limnogonus sp. & Gerridae & Hemiptera & 6 \\
11 & Microvelia dauglasi & Vellidae & Hemiptera & 18 \\
12 & Agriocnemis femina femina & Coenagrionidae & Odonata & 140 \\
13 & Conocephalus longipennis & Tettigoniidae & Orthoptera & 12 \\
\hline \multicolumn{2}{c}{ Jumlah (ekor) } & & & 1.216 \\
\hline B & Parasitoid & & & \\
1 & Pipunculus mutillatus & Pipunculidae & Diptera & 9 \\
2 & Apanteles baolis & Braconidae & Hymenoptera & 10 \\
3 & Telenomus rowani & Scelionidae & Hymenoptera & 20 \\
\hline Jumlah (ekor) & & & 39 \\
\hline Jumlah (A+B) & & & 1255 \\
\hline
\end{tabular}

Berdasarkan statusnya, antropda musuh alami yang diperoleh di lahan lebak tengahan yang berperan sebagai predator sebanyak 13 spesies dan yang berperan sebagai parasitoid sebanyak tiga spesies.

Populasi antropoda predator tertinggi pada lahan lebak tengahan adalah Paederus fuscipes, diikuti oleh Ophionea sp.,
Micraspis sp., Agriocnemis femina femina, dan Lycosa pseudoannulata, sedangkan antropoda predatorlainnya dalam jumlah rendah. Populasi antropoda parasitoid tertinggi adalah Telenomus rowani sedangkan antropoda parasitoid lainnya dalam jumlah rendah 
Farida Adriani \& Nur Hafizah, Keanekaragaman musuh alami..

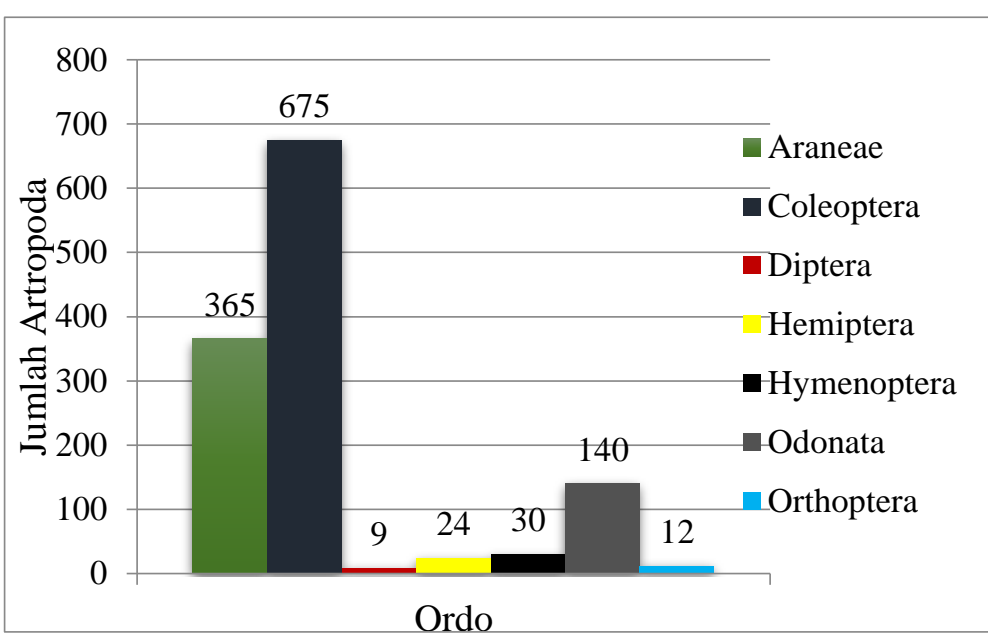

Gambar 2. Histogram populasi atropoda musuh alami yang didapat pada lahan lebak tengahan

\section{Lahan Lebak Dalam}

Artropoda musuh alami yang didapat pada lahan lebak dalam terdiri dari 16 spesies yang terbagi dalam tujuh ordo yaitu ordo Araneae (lima spesies), Coleoptera (empat spesies), Diptera (satu spesies), Hemiptera (dua spesies), Hymenopera (dua spesies), Tabel 3. Spesies antropoda musuh alami serta statusnya pada lahan lebak dalam di Desa Rantau Karau Raya Kecamatan Sungai Pandan Kabupaten Hulu Sungai Utara

\begin{tabular}{|c|c|c|c|c|}
\hline No. & Spesies (jenis) & Famili (keluarga) & Ordo (Bangsa) & $\begin{array}{l}\text { Jumlah } \\
\text { (Ekor) }\end{array}$ \\
\hline & Predator & & & \\
\hline A & Argiope catemula & Araneidae & Araneae & \\
\hline 1 & Lycosa pseudoannulata & Lycosidae & Araneae & 20 \\
\hline 2 & Oxyopes javanus & Oxyopidae & Araneae & 105 \\
\hline 3 & Phidippus sp. & Salticidae & Araneae & 78 \\
\hline 4 & Tetragnatha sp. & Tetragnathidae & Araneae & 71 \\
\hline 5 & Harmoniaoctomaculata & Coccinellidae & Coleontera & 112 \\
\hline 6 & Micrasnis sn & Coccirellidae & Coleoptera & 8 \\
\hline 7 & Anhioneg sp. & Carabidae & Coleoptera & 346 \\
\hline 8 & Dpromea sp. & Calaviuat & Coleoptera & 125 \\
\hline $\begin{array}{l}0 \\
9\end{array}$ & raederus jusctpes & Staphylinidae & Coleoptera & 180 \\
\hline & Limnogonus sp. & Gerridae & Hemiptera & 8 \\
\hline 10 & Microvelia dauglasi & Veliidae & Hemiptera & $\begin{array}{l}8 \\
0\end{array}$ \\
\hline 11 & Agriocnemis & Coenagrionidae & Odonata & 9 \\
\hline 12 & femina & Tettigoniidae & Otthoptera & 107 \\
\hline 13 & Conocephalus & & & \\
\hline & longipennis & & & \\
\hline & mlah (ekor) & & & 1.179 \\
\hline $\mathrm{B}$ & Parasitoid & & & \\
\hline 1 & Pipunculus mutillatus & Pipunculidae & Diptera & 10 \\
\hline 2 & Anagrus optabilis & Mymaridae & Hymenoptera & 7 \\
\hline 3 & Elasmus claripennis & Elasmidase & Hymenoptera & 11 \\
\hline Jum & h (ekor) & & & 28 \\
\hline Jum & $h(A+B)$ & & & 1.207 \\
\hline
\end{tabular}

Odonata (satu spesies) dan Orthoptera (satu spesies).

Hubungan antar ordo dan populasi antropoda yang didapat pada lahan lebak tengahan disajikan pada Gambar 3 dan Tabel 3. 


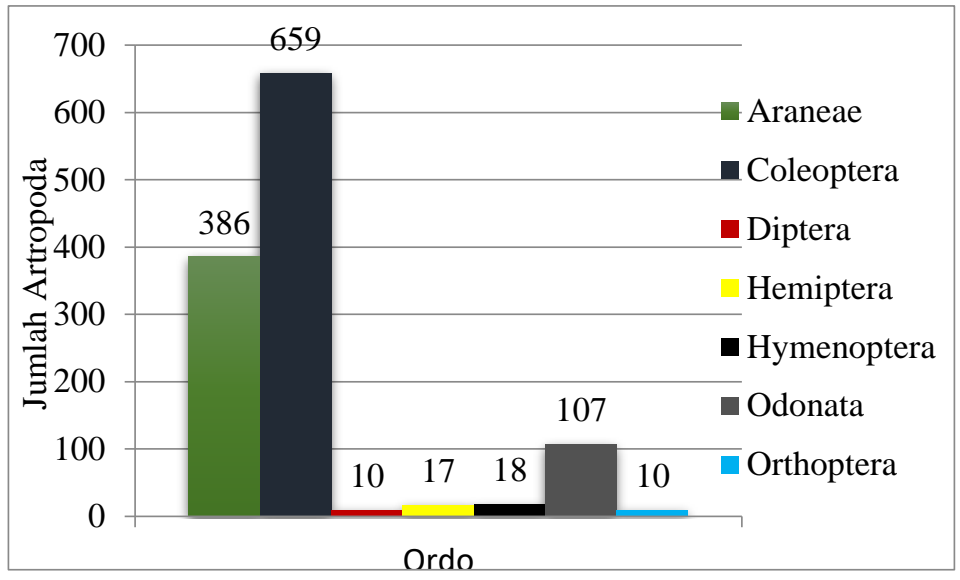

Gambar 3. Histogram populasi artropoda musuh alami yang didapat pada lahan lebak dalam

Berdasarkan statusnya, antropoda musuh alami yang diperoleh di lahan lebak dalam yang berperan sebagai predator sebanyak 13 spesies dan yang berperan sebagai parasitoid sebanyak tiga spesies. Populasi artropoda predator tertinggi pada lahan lebak dalam adalah Micraspis sp., diikuti oleh Lycosa fuscipes, Ophinea sp., Agriocnemis femina femina, Tetragnatha sp., dan Lycosa pseudoannulata, sedangkan artropoda predator lainnya dalam jumah rendah.
Populasi artropoda parasitoid tertinggi adalah Pipunculus mutillatus dan Elasmus claripennis sedangkan artropoda parasitoid lainnya dalam jumlah rendah.

Hasil analisis populasi artropoda pada lahan lebak dangkal, lebak tengahan dan lebak dalam baik secara keseluruhan maupun terhadap masing-masing status artropoda disajikan pada Tabel, 4, 5, 6 dan 7.

Tabel 4. Hasil analisis populasi artropoda musuh alami pada lahan lebak dangkal, lebak tengahan dan lebak dalam

\begin{tabular}{lcccc}
\hline \multicolumn{1}{c}{ Lahan } & $\begin{array}{c}\text { Indeks } \\
\text { Dominasi }(\mathrm{C})\end{array}$ & $\begin{array}{c}\text { Tingkat } \\
\text { Kesamaan }(\mathrm{E})\end{array}$ & $\begin{array}{c}\text { Indeks } \\
\text { Kekayaan Jenis }(\mathrm{R})\end{array}$ & $\begin{array}{c}\text { Indeks } \\
\text { Keragaman }\left(\mathrm{H}^{\prime}\right)\end{array}$ \\
\hline Lebak Dangkal & 0,151 & 0,175 & 2,652 & 0,525 \\
\hline Lebak Tengahan & 0,136 & 0,181 & 2,102 & 0,501 \\
\hline Lebak Dalam & 0,150 & 0,183 & 2,116 & 0,507 \\
\hline
\end{tabular}

Tabel 5.Hasil analisis populasi artropoda musuh alami pada lahan lebak dangkal

\begin{tabular}{lcccc}
\hline \multicolumn{1}{c}{ Status } & Indeks Dominasi (C) & $\begin{array}{c}\text { Tingkat } \\
\text { Kesamaan }(\mathrm{E})\end{array}$ & $\begin{array}{c}\text { Indeks } \\
\text { Kekayaan Jenis (R) }\end{array}$ & $\begin{array}{c}\text { Indeks } \\
\text { Keragaman (H') }\end{array}$ \\
\hline Predator & 0,161 & 0,202 & 1,964 & 0,548 \\
\hline Parasitoid & 0,271 & 0,409 & 1,070 & 0,658 \\
\hline
\end{tabular}

Tabel 6. Hasil analisis populasi artropada musuh alami pada lahan lebak tengahan.

\begin{tabular}{lcccc}
\hline \multicolumn{1}{c}{ Status } & Indeks Dominasi (C) & $\begin{array}{c}\text { Tingkat } \\
\text { Kesamaan }(\mathrm{E})\end{array}$ & $\begin{array}{c}\text { Indeks } \\
\text { Kekayaan Jenis }(\mathrm{R})\end{array}$ & $\begin{array}{c}\text { Indeks } \\
\text { Keragaman }\left(\mathrm{H}^{\prime}\right)\end{array}$ \\
\hline Predator & 0,144 & 0,203 & 1,689 & 0,521 \\
\hline Parasitoid & 0,361 & 0,645 & 1,546 & 0,709 \\
\hline
\end{tabular}

Tabel 7. Hasil analisis populasi artropoda musuh alami pada lahan lebak dalam. 
Farida Adriani \& Nur Hafizah, Keanekaragaman musuh alami..

\begin{tabular}{lcccc}
\hline \multicolumn{1}{c}{ Status } & Indeks Dominasi (C) & $\begin{array}{c}\text { Tingkat } \\
\text { Kesamaan (E) }\end{array}$ & $\begin{array}{c}\text { Indeks } \\
\text { Kekayaan Jenis (R) }\end{array}$ & $\begin{array}{c}\text { Indeks } \\
\text { Keragaman (H') }\end{array}$ \\
\hline Predator & 0,157 & 0,204 & 1,699 & 0,522 \\
\hline Parasitoid & 0,390 & 0,636 & 1,600 & 0,699 \\
\hline
\end{tabular}

\section{Pembahasan}

Beragamnya spesies artropoda yang ditemukan baik pada lahan lebak dangkal, lebak tengahan dan lebak dalam diduga disebabkan ekosistem persawahan tersebut menyediakan lingkungan yang sesuai bagi pertumbuhan dan perkembangan artropoda tersebut, baik sebagai tempat mencari makan, memperbanyak keturunan atau hanya sekedar berlindung sementara. Kelimpahan musuh alami sagat tergantung pada kelimpahan dan keanekaragaman mangsanya yang secara tidak langsung terkait dengan kekayaan vegetasi yang tersedia.

Apabila dilihat, jumlah spesies artropoda pada lahan lebak dangkal jumlahnya lebih besar yaitu 20 spesies, dibandingkan dengan artropoda yang terdapat pada lahan lebak tengahan yaitu 16 spesies dan pada lahan lebak dalam yaitu 16 spesies. Hal ini dikarenakan lahan lebak dangkal, hanya tergenang sedikit air jika dibandingkian dengan lebak tengahan dan lebak dalam, sehingga spesies artropoda lebih dapat berkembang biak. Selain itu, lahan lebak dangkal lebih banyak menyediakan makanan bagi spesies artropoda.

Berdasarkan hasil analisis populasi, indeks dominasi (C) artropoda pada lahan lebak dangkal lebih tinggi yaitu 0,150, dibandingkan dengan indeks dominasi artropoda pada lebak tengahan yaitu 0,136 dan lebak dalam yaitu 0,150 . Hal ini menunjukan bahwa tidak ada spesies artropoda yang mendominasi pada ketiga lahan lebak tersebut. Dianthani (2003) dalam Karnadi (2007) bahwa apabila C mendekati 0 berarti tidak ada spesies yang mendominasi dan bila $\mathrm{C}$ mendekati 1 berarti ada spesies yang mendominasi. Hasil analisis tingkat kesamaan (E), pada lahan lebak dangkal yaitu 0,175 , lebak tengahan 0,181 , dan lebak dalam 0,183 . Hal ini berarti bahwa adanya spesies artropoda yang sama pada lahan lebak dangkal lebih rendah dibandingkan pada lebak tengahan dan lebak dalam. Sedangkan indeks kekayaan jenis (R) artropoda pada lebak dangkal lebih tinggi yaitu 2,652, dibandingkan dengan lebak tengahan yaitu 2,116 . Hal ini menunjukan bahwa spesies atropoda pada lebak dangkal lebih banyak dibandingkan dengan lebak tengahan dan lebak dalam. Hasil analisis indeks keragaman (H') menunjukan bahwa pada lebak dangkal ternyata nilainya lebih tinggi yaitu 0,525 dibandingkan dengan lebak tengahan yaitu 0,501 dan lebak dalam yaitu 0,507. Dianthani (2003) dalam Karnadi (2007) bahwa apabila H' $<2,3036$ berarti keanekaragaman kecil dan kestabilan komuntias rendah. Hal ini berarti pada ketiga lahan lebak memiliki keanekaragman yang kecil dan kestabilan komunitas yang rendah walaupun tidak berbeda jauh.

Perbedaan-perbadaan nilai indeks keragaman dan dominasi yang disajikan pada tabel 6, sejalan dengan konsep keanekaragaman Sogianto (1994) yaitu suatu komunitas dapat dikatakan mempunyai keanekaragaman jenis yang lebih tinggi apabila komunitas itu disusun oleh banyak spesies (jenis) dengan kelimpahan spesies yang sama / hampir sama atau mempunyai dominasi yang rendah.Sebaliknya jika komunitas itu disusun oleh sangat sedikit spesies dan dengan dominasi yang tinggi maka keanekaragaman jenisnya rendah. Keanekaragaman jenis yang tinggi menunjukkan bahwa komunitas tersebut memiliki kompleksitas yang tinggi dengan interaksi spesies yang tinggi pula.

\section{KESIMPULAN}

Jumlah artrhopoda musuh alami yang ditemukan pada lahan lebak dangkal yaitu 20 spesies yang terdiri dari tujuh ordo, sedangkan pada lebak tengahan dan lebak dalam masing-masing terdapat 16 spesies yang terdiri dari tujuh ordo. Populasi artrhopoda predator tertinggi pada lahan lebak dangkal adalah Micraspis sp., sedangkan pada lebak tengahan adalah Paederus fuscipes, dan pada lebak dalam 
adalah Micraspis sp. Indeks keragaman artrhopoda musuh alami pada ketiga lahan tergolong rendah.

\section{DAFTAR PUSTAKA}

Ar-Riza, I., N. Fauziati dan Noor, D. H. 2008. Kearifan lokal sumber inovasi dalam mewarnai teknologi budidaya padi di lahan rawa lebak. Balai Penelitian Pertanian Lahan Rawa. Banjarbaru.

Dinas Pertanian dan Hortikultura Provinsi Kalimantan Selatan. 2012. Laporan Tahunan. Banjarbaru. Kalimantan Selatan.

Jumar. 2004. Entomologi Pertanian. PT. Rineka Cipta. Jakarta.

Karnadi, H. 2007. Studi populasi arthnopedi pada tanaman padi sistem pertanian organik. Skripsi. Fakultas Pertanian Unlam. Banjarbaru

Ludwig, J. A. and J. F. Reynold. 1988. Statistical Ecology. John Willey and Sons. New York.

Mahrub, E. 2004. Kajian keanekaragaman arthropoda pada lahan padi sawah tanpa pestisida dan manfaatnya dalam pengendalian hama terpadu. Jurnal Perlindungan Tanaman Indonesia Vol. 5
No. 1. Fakultas Pertanian Universitas Gadjah Mada. Yogyakarta.

Simanungkalit, Dj. 2004. Key Note Speech. Seminar regional optimalisasi penggunaan agen hayati sebagai alternatif pengendalian opt pada pertanian berkelanjutan yang ramah lingkungan. 25 September 2004. Banjarbaru.

Siswanto dan I. M. Trisawa. 2000. Keanekaragaman serangga yang berasosiasi dengan tanaman obat di kebun koleksi Balitra. Prosiding Simposium Keanekaragam Hayati Arthropoda Pada Sistem Produksi Pertanian. Cipayung, 16-18 Oktober 2000. Bogor. Hal. 133-148.

Soegianto, A. 2004. Ekologi Kuantitatif. Metode Analisis Populasi dan Komunitas. Penerbit Usaha Nasional. Surabaya-Indonesia.

Sosromarsono, S. dan Untung. 2000. Keanekaragaman hayati arthropoda predatordan parasitoid di indonesia serta pemanfatannya. Prosiding Simposium Keanekaragaman Hayati Arthropoda Pada Sistem Produksi Pertanian. Cipayung, 16-18 Oktober 2000. 